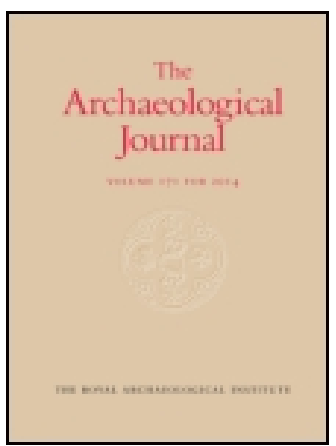

Archaeological Journal

\title{
The Evolution of Worcester
}

\section{J. W. Willis-Bund F.S.A.}

To cite this article: J. W. Willis-Bund F.S.A. (1906) The Evolution of Worcester, Archaeological Journal, 63:1, 201-230, DOI: 10.1080/00665983.1906.10853029

To link to this article: http://dx.doi.org/10.1080/00665983.1906.10853029

曲 Published online: 17 Jul 2014.

Submit your article to this journal

III Article views: 2

Q View related articles $\asymp$ 


\section{THE EVOLUTION OF WORCESTER. ${ }^{1}$}

By J. W. WILLIS-BUND, F.S.A.

A French writer gives as the sequence in the evolution of a French colony, "A barrack, a cafe, a prison." The sequence in the evolution of many of our English cities may be said to be a fort, a religious house, a town, especially if, like Worcester, the city is on the march or border of a tribal district. The Severn in early times was a great frontier river, crossed at certain places by well known fords. At or near these fords there dwelt persons, plunderers, or protectors, or both, of those who had to cross the ford. The rude huts of these watchers required some protection against the incursions of beasts or Britons. The protection would probably take the form of a palisaded bank enclosing the huts, thus rendering them to some degree defensible against either class of assailant. These huts with their protecting bank formed the fort.

When the missionary zeal of Archbishop Theodore sent forth priests to convert the heathen Saxon, they would naturally seek these village forts as the only shelter the country afforded, and the travellers who crossed the ford would furnish them with "occasions to be improved"; hence advantage was taken of these spots making them the headquarters of the missionary bands. The priests who formed these bands lived together and constituted the religious house.

The fort and the religious house, protecting and protected, could not fail to attract persons who desired a refuge from foes either temporal or spiritual, so under the shadow of the fort and the religious house people came and dwelt to secure the advantages of both worlds, hence the town.

Such was the normal growth of an English city. Each city, while following this general outline, had peculiarities of its lown which gives its history a special interest.

1 Read at the Anuual Meeting of the Institute at Worcester, 27th July, 1906. 
The peculiarities arise from local circumstances and difficulties, which show how matters were dealt with in the different cases. This paper is an attempt to show how Worcester dealt with hers.

The first thing necessary to understand the evolution of Worcester is to get a clear idea of her geographical position.

(1) On both banks east and west of the Severn for some distance above and below Worcester ran a great forest or sparsely populated waste. In traversing this, such travellers as there were had always to be on their guard against robbers and wolves, so some place where the dangers could be reduced to a minimum was selected where travellers would be obliged to halt.

(2) They were compelled to stop on the river banks. Then, and for years afterwards, the Severn was a tidal stream; up to and above Worcester the tide regularly ebbed and flowed. The ford was therefore not passable at all times of the day, sothat travellers who wanted to cross had to wait until the tide served for the passage. Only those who lived on the spot could tell when that would be, so a halting place on the river bank was a necessity. Hence the origin of the huts near the ford, to protect the travellers and their goods while they waited, to quote an old statute, "Essaying to pass over."

(3) Somewhere near on the east of the ford, although the exact spot is uncertain, the track that crossed the river and ran through the forest from east to west was intersected by the track that ran from north to south. This made the halting place of more importance as the ford was more used.

The ford and the intersection of tracks are therefore the origin of Worcester. They made some halting place on the river bank necessary. Such a place was not easy to find ; the land adjoining the Severn hereabouts is almost all on a level, and the fall of the river between Worcester and Gloucester is insignificant. The height of Worcester above sea level is even less than 100 feet. At high water the marshes and low-lying lands must have been almost impassable, hence if a site in their midst could be found near the river, it would possess the advantage of being defended by the marshes and by the river. Such a 
spot existed : a great mound, flat topped, running parallel to the river, bounded on the south and east by a brook, on the west by the river, was precisely what was required. This mound, the tump on which the cathedral now stands, formed the first settlement at Worcester.

The history of this tump is really the history of the city. On the south side of it, in all probability, were placed the huts, enclosed by a bank overlooking the river. All traces of these have long ago passed away, but along the brook that here joined the river, until recent times, there were remains of a bank, which, although often altered and renewed, may well have been on the site of, or even part of, the early settlement.

A few rude huts encircled by a bank was the starting point of Worcester. The first matter of interest is: What was the name?

If, instead of being on the east side of the Severn they had been on the west, or if Welsh had then been the spoken language of the district, there can be no doubt that a group of huts encircled with a bank would have been called "Llan," with some distinctive local or religious suffix. This was the case on the fords higher up the Severn and on the fords of the next great river to the west, the Wye. How the place escaped from the Welsh name, or how the Welsh name was supplanted by another, is not easy to say. That Welsh was spoken in the district seems clear from some of the place-names. Lower down the river towards Gloucester one of the fords or passing places still bears the Welsh name for a ford, "Rhydd," while others are called by the non-Welsh name of "Lode." For some reason the two most important crossings of the Lower Severn, possibly because they were occupied by Romans, have lost their local names and acquired the term "cestre." It is known that the one, Gloucester, was a Roman town; it is conjectured that the other, Worcester, was also a town or village in Roman times.

It is impossible to form any idea as to when the settlement at the ford was first formed-probably long before historic or Roman times-for there must have always been some line of communication across the river from east to west, probably past the great fort (the Herefordshire 
Beacon) which guarded the pass over the Malvern Hills. The fuct, which is usually admitted, that Worcester lay off the line of any of the great Roman roads, points to the ford having a pre-Roman origin. Possibly, when in Roman times the ford came to be more used, the old name was lost and the later name substituted as the settlement increased in importance and developed into a village. But as to this $\mathrm{Mr}$. Haverfield says that Worcester was of so little importance in Roman times that:

"not only is the Romano-British name of the place unknown nor has any probable conjecture ever been suggested concerning it."

The earliest name for the place in the Saxon charters is "Wigeran" or "Wiogeran ceastre."2 This Mr. Haverfield says has nothing to do with the Hwicci, and

"is probably not English at all but may conceivably contain some vestige of a British name."

So it will not do to trust too much to the evidence of the name to prove that the settlement at the ford was occupied by Romans. The existence of the ford and settlement are certain; the uncertainty is not the ford nor the origin, but merely, Did the Romans ever occupy the shelter? a point, after all, of but minor importance.

It is a more difficult matter to localise the ford. All, or almost all, the writers on Worcester have escaped the difficulty by evading it. It is, however, a point of such importance in the history of Worcester that an attempt should be made to meet it. There is no direct evidence on the subject, but something of a case can be made out for the south side of the present city. It is clear that the city did not then extend up the river for any distance. It could not extend below, for what are now the Diglis meadows, between Diglis House and Berwick's Brook, was then a swampy marsh which has gradually silted up to its present level. This is shown by the fact that in 1844, when the new cut to the navigation lock at Diglis was being made, at a depth of 20 feet, animal bones, pieces of pottery, and a coin of Marcus Aurelius ${ }^{3}$ were found, thus showing that if that was the then level the subsequent silting must have been

\footnotetext{
1 Tictoria History (Worcester), 2 Kemble Cod. Dipl. No. 1075. I, 204.

3 Allies' Antiquities, p. 28.
} 
To face page 204.

No. 1.

3

2)

$\Gamma^{-}$

2

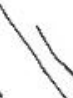

.

II

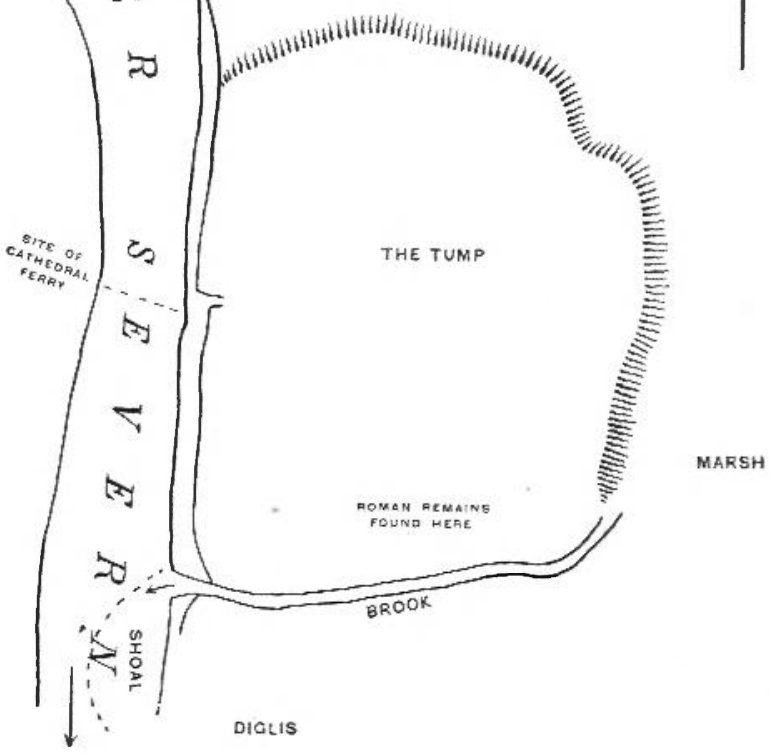

운

500

1000 Feet 
very great. Far later in the thirteenth century it appears that a marsh extended on the east side of the city to the bottom of Friar Street. ${ }^{1}$ It therefore seems that on the south side of the town below the cathedral tump there was a bog, a place not offering a good entrance to, or exit from a ford. The site must therefore have been somewhere between the south side of the cathedral tump and where the old bridge crossed the river at the bottom of Newport Street. As far as is known, there was no ford across the river at the bridge or for some way below. It is clear that in the fifteenth century there was deep water on the west bank, for the city ordinances directed the filth of the city to be cast into the river there, not on the shallows on the east side $^{2}$; consequently, as far as can be said, there was no ford until a point to the south of the cathedral was reached just below the south side of the tump. A brook used to run into the river here which was at a later time called "Frog Brook"; at the time of the civil wars it was so considerable a stream as to turn a mill adjoining the tump. This brook was covered in at a later date, and its course called "Frog Lane." The gentility of the Worcester City Council has led them to commit the sin of removing their neighbour's landmarks by getting rid of this and a number of other old local names because they were "vulgar," so the course of the brook is now called Diglis Street. Where the brook joined the Severn, and for some distance below a large shoal, known as "Diglis Shoal," used to exist until it was dredged out to improve the river for navigation purposes. This shoal, it seems probable, marked the site of the ford.

Another reason for thus thinking, is, that this is the only spot that in old times the fortifications of the place commanded; if the river had been fordable at any spot to the north of this tump the town would have been unprotected. The fact that practically the city was left undefended between the tump and the bridge, and that no defensive works were ever placed on the west bank,

1 Ann. Wig. Rolls ed., p. 537. The friars' burial ground situate here is said "tempore hyemali mersus dicetur melius quam sepultus." 
leads to an inference that the fort on the tump guarded the ford. There are further reasons. If it was asked what evidence of the existence of a settlement such as that which it has been said existed at the ford would be expected to be found in excavating on the site, the answer would be coins and pottery. Excavations have been made on and along the tump up the north side of the brook at different times upon the suggested site of the settlement, and the result has been to find various articles which are to all appearances either late Celtic or Roman pottery and Roman coins.

"None of them point to a single recognisable trace of any definite kind of building, public or private. Still the number and character of the certain and probable items is significant and seems to justify the idea of the existence of a small country town or village." 1

Besides the pottery a number of first and second century coins have been found at the spot, and their comparative frequency suggests that the village or huts were

"already in existence before or in the early part of the Roman occupation." :

The fact of the existence of these relics at the spot where it is suggested the fort or shelter stood, and the further fact of the shoal being just under the settlement or fort, are the basis from which it seems fair to draw the inference that here on the tump was the fort and below it the ford.

It is just possible that the cathedral ferry which still exists a few yards higher up the river may be the modern survival of the ancient ford-at least, it marks the line of a track leading from the east to the tump.

This is all that can be said as to the first stage in the history of Worcester - the fort, and its origin. Popular writers say that Worcester was not merely a Roman town, but also it was the Hwiccian capital. The point as to the Roman town has been dealt with. As to the Hwiccian capital there are difficulties. (1) It is not by any means certain that the Hwicci had a capital at all; (2) assuming that they had, there is nothing in any way to show that capital was Worcester. There were other places in their supposed territory which are equally probable or improbable.

1 Tictoria History, I, 207.

2 Ibid., 208. 
II. Assuming that the existence of the fort, or rather the enclosed settlement on the tump, is established, the next point in the order of development is the Religious House. Here we get on firmer ground. About 655 the missionary priests who sought to convert the pagan Saxons, had wandered through the Mercian forest as far as the Severn, and some of them reached the fort overlooking the Severn ford. From the intersection of the tracks it was a convenient centre for evangelising the forest, and the clergy soon made it their headquarters. It was deemed necessary to have someone to be at the head of these priests, and a monk came from the great monastery of St. Hilda at Whitby for the purpose, and became the first Worcester bishop; this is said to have been in 680 , the date of the consecration of Bosel by Archbishop Theodore. Bosel came to Worcester and took up his residence on the tump. There for upwards of 1,200 years his successors have been settled. The story of Worcester for the next 1,100 years is the story of the Worcester monastery.

On several points of interest in connection with the new monastery. Did the clergy occupy the whole of the tump and eject the earlier dwellers? Did the fort and ford still remain? Did the clergy only occupy the part not included in the fort? How long did the ford continue and when was it superseded by a bridge? As to all these there are no data to go upon.

Very soon after the clergy came, a church was built and grants of land made to it. It was dedicated in honour of St. Peter ; this, Stubbs says, was in the seventh century. ${ }^{1}$

What was this church? All writers say the first cathedral at Worcester, but there is another view. On the bank of the old Frog brook still stands a church of St. Peter, not a monastic, but a parish church, and this, if not within the limits of the old settlement, was close on its borders. Further south and further east the Diglis swamp prevented the settlement extending. It is suggested that this church of St. Peter the Great was the original church of the Worcester settlement, the first church built in Worcester. It is said to have existed in 
the time of Bishop Ostfor before 700.' If this view is accepted, it would seem that the clergy settled on the vacant space on the east side of the tump; the lay settlement continuing enclosed on the south side; here outside the enclosure stood the church.

The clergy who were settled at Worcester do not appear to have followed any regular rule or order. Soon after they came their settlement was surrounded by a bank or by a palisade, but whether it was part of the old fort or a new enclosure is not quite clear. It may have been an additional enclosure, which would seem to exclude the church of St. Peter. That some such enclosure was made at an early date is clear. It would have been strange if it was not so. In those wild times the monastery would not have felt safe if raiders from the land or the river could have attacked it and robbed it without any obstruction. The precise extent of the enclosure is not certain, but it is suggested that it contained all the tump, as that had early become a separate parish with its own church, a parish which included all the land on which the monastery and bishop's palace afterwards stood, but did not include St. Peter's church and the houses round it. There is no clear evidence as to when the tump parish church was built, but it is suggested that from its dedication it was built at an early date as the church is dedicated in honour of the archangel Michael. As has been said, the tump was inhabited from early times, and in all probability the early dwellers on it were heathen and offered up heathen worship and heathen sacritices. When a place that had been the site of heathen worship became the site of a Christian church in order to show and to emphasise the triumph of the angels of light over the powers of darkness, a dedication to the great Christian standard-bearer Michael was very common. It would therefore be in accordance with the usual practice if the church erected on the tump to celebrate the triumph of the power of Heaven, was in honour of St. Michael. The importance of this is, the indication that this church was one of the earliest ones erected here soon after the establishment of

1 Thomas, Survey Worcester Cathedral, p. 7. 
the clerical colony. ${ }^{1}$ If this is so, it does not seem likely that inside the monastic enclosure there would be a church of St. Michael and a church of St. Peter, especially when it is clear there was a parish and parish church of St. Peter close outside the enclosure.

There is also another point. When Worcester was divided into parishes the monastic enclosure of St. Michael formed a separate parish, which was always in the county of Worcester, and outside the city, while the church of St. Peter and the houses round it were always in the city. If the view here put forward that the church of St. Peter and the old settlement remained, after the coming of the monks, in its old enclosure, and this was part of, if not the whole of, the old lay settlement, when the monks enclosed the rest of the tump as their territory, and built there their own chruch of St. Michael, which was always outside the city, it goes some way towards offering an explanation of some local peculiarities in the development of Worcester that it is otherwise difficult to explain. There are further points that require to be considered, such as the fact that the area of St. Peter extended a long way outside the city, and that there was a church of St. Peter in the castle; but they do not necessarily contradict this view.

Among the early documents relating to the Worcester Church is one given by Heming ${ }^{2}$ that causes some difficulty; it is called a Synodal decree, and is said to have been obtained by Bishop Wilfrith in 796, by which it was ordered that the monastery of Withington in Gloucestershire should, after the death of the Abbess that then held it, be annexed to the see of Worcester (Werincester). In 774, Bishop Mildred ${ }^{3}$ had given this land to the Abbess Ethelburgha for her life, and after her death it was to return to " the Church of St. Peter, in Wcagemceston, which is the Pontifical see of the Wiccians." This, therefore, shows that at all events at this time the Church of St. Peter was regarded as the chief church in

I From an entry in the Sede Vacante
Register, as to Ginsborough's enthrone-
ment, it appears to have been in
1303 an ancient custom for the Bishop
to put on his vestments in St. Michael's
Church and enter the Cathedral from there by the north transept. $\mathrm{S}$. V. Reg.

(W. H. S.), p. 53.

Chart. (ed. Hearne), ii, 464.

3 Ibid. 
Worcester. Another charter in 775 gives land at Stoke, on the east side of the Salwarpe, to the brethren serving God in the monastery at Wigonne, built in honour of the Most Holy Virgin Mary, the Mother of our Lord. ${ }^{1}$ Therefore it seems that in the eighth century the state of things was, the Church of St. Peter, the Episcopal Church; and apart and distinct from it, the Monastery of St. Mary.

There is nothing to show if St. Peter's, the episcopal church, and the parish church, are one and the same, or not; nor if there was a church attached to the monastery of St. Mary, or whether St. Michael's was or was not that church. Most writers have assumed a cathedral of St. Peter in the monastic enclosure, which was also the church of the monastery, but the evidence does not seem to bear this out. There was a church of St. Peter's outside, and a church of St. Michael's inside ; but that is about as far as can be said with any certainty. But it is most probable if St. Michael's was not the monastic church, that such a church also existed inside the monastic enclosure.

This completes the early account of the monastery. Under its shadow, as in so manyother cases, a town began to arise. This town was more than a mere expansion of the old settlement. It does not seem to have greatly interfered with it, but it so increased that a church became necessary, and one was built on the north side the tump in the new group of houses, and dedicated to St. Helena. At some time after, another church adjoining St. Helen's was built and dedicated to the Martyr Alban. Later, a quarrel arose between these churches as to which of them was the oldest. The matter at a subsequent date gave rise to a good deal of friction, St. Helen's claiming to be the Mother Church of Worcester and as such to have certain rights over the others. The question came before a synod held by Bishop Wustan in 1092, which came to these very remarkable conclusions. ${ }^{2}$

(1) That the only parish in the city of Worcester was that of the Mother Church.

I Birch Cart. Sax., I, 289.

2 Heming Charlul. (Hearne ed.), II, 628, 930 . 
(2) That the vicarage of the Mother Church of St. Helen's has existed from the time of King Athelred and Archbishop Theodore, who founded the place and made Bosel first bishop in 680 .

(3) That this order of things continued from the time of Bosel to that of Oswald, who, by the permission of Edgar and by the authority of Archbishop Dunstan, on account of the irregular lives of the secular clergy, substituted the regular lives of the monks in 969.

(4) At this time Wynsin was vicar of St. Helen's. At Oswald's request he and the other priests who served there became monks and handed over the church of $\mathrm{St}$. Helen and its possessions to the use of the monastery. In return Oswald made Wynsin Prior of the Worcester House, and granted to him and all successive Priors of Worcester that they should be over all the churches and priests in that town. No dean, archdeacon, or other official, except the Prior, could exercise jurisdiction.

If this document is genuine, and gives a correct account of what took place at the synod, St. Helen's was in a very remarkable position. She was the only parish church in Worcester, the others were all chapels, and from this position she became the Mother Church. No mention is made of St. Peter or of St. Michael's. It seems to leave the tump and its houses alone, and only to deal with the houses to the north of the tump.

If, as has been suggested, St. Peter's had been the church with the bishop's throne, the first church of all, St. Helen's would have no jurisdiction over it; as to St. Michael's, St. Helen's would have no jurisdiction, as St. Michael's was in the county and St. Helen's jurisdiction was confined to the city. To some slight extent, therefore, this bears out the suggestion here put forward that the order of churches was, St. Peter's the church of the original settlement, St. Michael's, the church of the monastery not in the city of Worcester ; and St. Helen's the church of the town; and it is quite possible that they were built in that order.

This decree of the synod bears out the statement that there was only one parish in the citv of Worcester, with a large number of chapelries, and if this is so it goes a long way to account for one or two points in the 
development of the city that are otherwise difficult to explain.

From an early period, as might have been expected, for the reasons already given as to the enclosure of the fort and the monastery, walls were built round the town. It is usually said that Worcester, having recently suffered from an incursion of Danes, between 573-899, obtained for its future protection from the earl and Lady of the Mercians, Aethelred and Aethelflaed, the leave of King Alfred, at the request of the Bishop Werefrid, permission to build the city walls, and that Aethelred and his wife gave a half of their rights in the city to the Bishop and St. Peter. ${ }^{1}$ It does not appear if this was the first time the Worcester walls were built or whether they had been built before and were now rebuilt. However that may be, this marks a further point in the development of the city, the town was walled in.

The next point is one of considerable difficulty. What was the area enclosed in the walls? Having regard to the statement of Wolstan's Synod that St. Helen's was the only parish in Worcester, it seems a not unfair inference to draw that the area of St. Helen's parish was the area enclosed. If the statement that the parish included a number of parochial chapels is true this would account for the other parishes that are now included in the area, the chapelries gradually becoming parishes. To some extent this riew is borne out by it consideration of the Manor of the Priory, which was called the Manor of the Guesten Hall. It is said-

"The boundaries of the manor of Guesten Hall (the hall of which yet remains within the precincts of the cathedral) cannot well be ascertained as they extend into all parts of the city and almost into every street where the church has either lands or houses."'?

A manor with its tenants scattered over various parishes would be a very unusual occurrence, but a manor with its tenants in various parts of the same parish, even if the parish were divided into chapelries, would not. If the parish of St. Helen was coterminous with the city, this would explain at once all the difficulties of the

1 The words are "for the love of God and for St. Peter and the church at Worcester, and at the request of Werfrid the Bishop, their friend Aetbelred the earldorman, and Aethel- flaed commanded the burh at Worcester to be built." Kemble, Saxons in England, I, 328, Cod. Dipl. No. 1075. Mr. St. John Hope has kindly given me this reference. Green, Hist. Worcester, II, 48. 


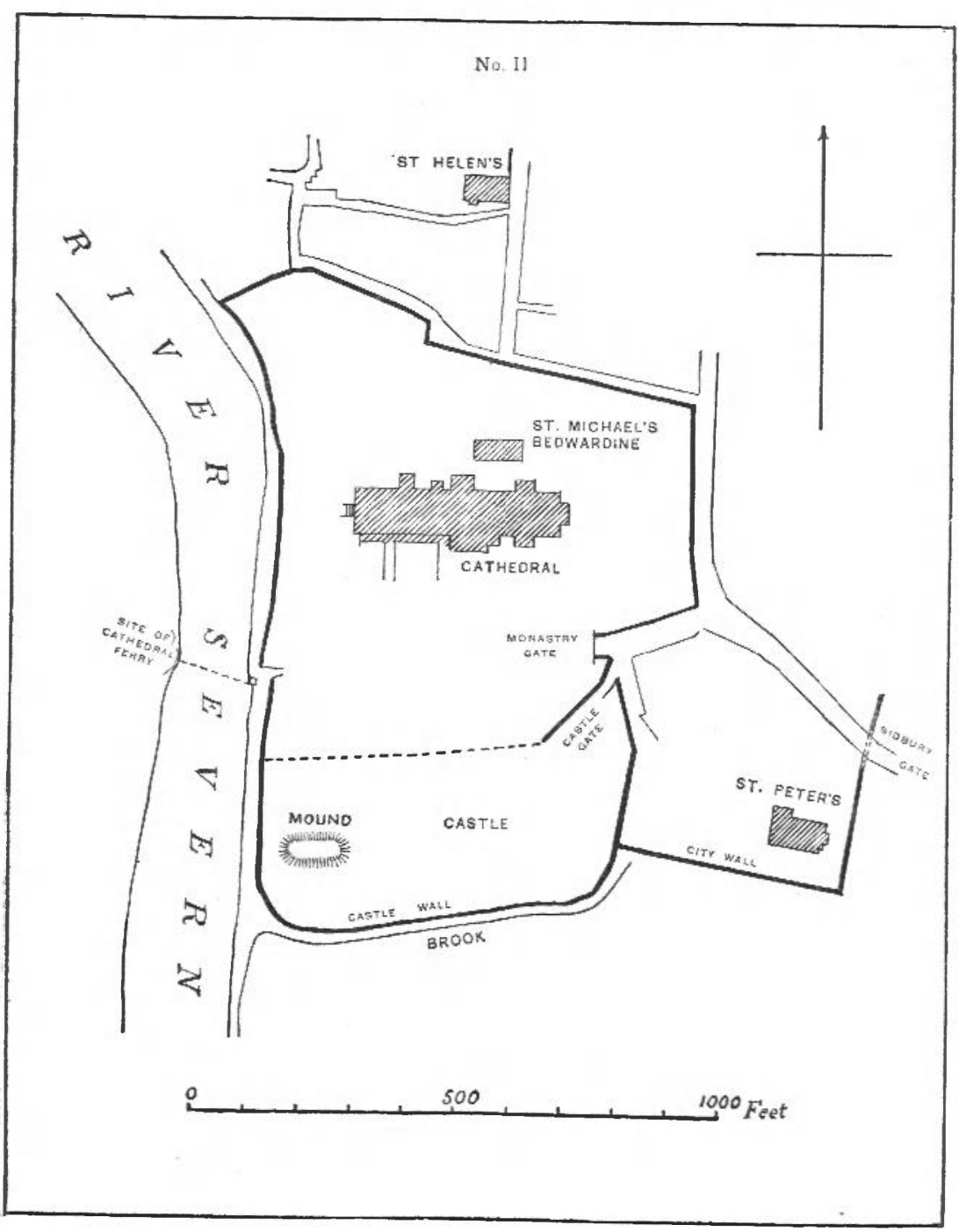


Guestenhall Manor, as the manor and parish would have originally had the same area. the anomaly arising from the boundaries of the parish becoming subsequently restricted to a part of the original parish could not occur.

This, however, does not quite explain the city area, that area and the parish of St. Helen were not coterminous. There were in addition parts of other parishes, St. Peter, St. Martin, St. Nicholas, and St. Clement, which were inside the city walls. As to St. Martin the parish included three manors, Cudley, Lippard, and Perry, which were and have always been in the county. A small portion of the parish was outside these manors; another was included within the city walls. Here the city took what was really no man's land and what would probably have more interest with the town than with the outside manors. The same reason applies to St. Clement's : part was on the east side of the river--this was included in the city walls ; part on the west-this was left out.

Somewhat similar is the case of St. Peter's. Here were also three manors, Battenhall, Barneshall, and Timberdine, which were all in the county and so remained, while the small piece adjoining the fort and the old settlement was included in the city. In each of these cases a definite area of the parish was included and another excluded.

This inclusion and exclusion offers a possible solution of what has long been a puzzle to the Worcester antiquaries ; to certain parishes a word has been added to the name "Bedwardine"; what does it mean? The parishes that have it are three: St. Michael, St. Nicholas and St. John, and any explanation of the name must have some reference to each parish. The local circumstances of each vary greatly. Habingdon, the first writer who tries to explain the word, says, speaking of St. Michael's :

"The church, shrouded under the wing of the cathedral church, in the heart of the sanctuary sheweth, as by the addition of the word Bedwarden, that she was under the jurisdiction of the warden of the bedes or prayers, and the parish of the inhabitants of the sanctuary, a place privileged from temporal exaction." ${ }_{1}$

1 W. H. S. History, II, 47. 
However well the explanation may suit St. Michael's it has no reference at all to either St. Nicholas or St. John's : neither of them can be said to be the parish of the inhabitants of the Sanctuary, nor are they in any way privileged from temporal exaction.

Green gives another definition. ${ }^{1}$

"Brod, in modern orthography Bred, is mensa, Brodern the table room is refectorium in Elfie's glossary, whence Brodworthig must be the table farm, i.e., the ground reserved for the supply of the refectory."

"In many places the Saxon word worthig, i.e., a large close, is corruptly changed into warden, worthin or worth. Thus, Bedwardine is the close or field for bread, i.e., to supply bread."

This definition might apply to St. John's, and to some extent to St. Nicholas, but an explanation which makes the supply to the refectory drawn from a parish consisting mainly of the cathedral cemetery is hardly satisfactory.

The latest writer on Worcestershire place-names adopts Green's explanation almost without any qualification :

“Bedwardine (St. John's and St. Michael's), Worcester, 1327, Bedewardyn, Nash ii, 308, because it was allotted to supply the table of the monks of Worcester with provisions. It is Anglo-Saxon : Beodworthyn, the table farm. Beod land is another term for land so appropriated."

It can only be repeated that this definition may apply to St. John's but could not apply to St. Michael's. There is, however, no evidence that St. John's was allotted to supply the table of the Worcester monks; on the contrary, in the Rent Roll of the Priory the rents they received from it are set out in full, and there seems to be no appropriation of any of them except a small part which was assigned to the anniversary of Prior Radulph. ${ }^{3}$

A different explanation, and one which has at least the merit of being applicable to all the parishes which have the name, has been put forward by Allies." After quoting Nash, ${ }^{5}$ who gives the same definition as that

1 Green, Hist. Worcester, II, $47 \mathrm{n}$.

- Duignan, Worcestershire Placenames, p. 16.

${ }^{3}$ Register Prioratus Wigorniensis,

4 Antiquities and Folklore of Worcestershire, p. 263.

5 Vol. II, p. 319. ed. Hale. p. 39.A. 
given by Green, "supplying the table of the refectory with provisions," Allies says :-

"A question, however, may be raised whether the prefix to the name Bedwardine does not come from the French 'bord' a border, and that it and the suffix mean the Bordworthig or boundary field or close of the city. The parish of St. Michael in Bedwardine is also on the boundary of Worcester."

If such a derivation is etymologically possible it does give a common basis applicable to each of the three parishes; St. Michael's was on the border of the city and the county, St. Nicholas had a part, an undefined part, of its area taken into the city; so had St. John's. And it may well be that when an undefined part of a parish partly or wholly in the city is included in or surrounded by it, the word is added to the name of the parish to show that such was the case. But when a defined part of the parish, as in the case of St. Martin and St. Peter, where outside as certain manors, or as in St. Clement's, all on the east of the river, is taken into the city, the word is not used. This would make the use of the word as showing that the parish that bore it had a portion of its area in one and a portion in another jurisdiction. The weak point in this is that it only appears to be used throughout Worcestershire in connection with Worcester, in other places it was "town " and "foreign." The story of St. John's to some extent supports and to some extent upsets this view, so it should be stated. From the earliest times until towards the end of the fourteenth century the parish of St. John's was known as the parish of Wyke. As its church was dedicated to St. Cuthbert it would appear to have been built at the time of some of the Whitby missionaries. It belonged to the Priory of Worcester and the church was at the extreme west side of the parish, some two miles from the Priory. There was, however, a chapel dedicated to St. John the Baptist within half a mile of the city. Whether it was that the monks had become lazy, or objected to going so far to serve the church, or whether the mortality caused by the Black Death had so reduced the number of monks that they could not discharge all their duties, does not appear, but for some reason the monks persuaded Bishop William de Lynne (1368-1373) to desecrate the church 
of St. Cuthbert and to create the chapel of Si. John the Baptist into a parish church where the original boundaries belonging to the chapelry of St. John, do not appear, but whatever they were, they ceased to exist, being merged in the parish, an undefined part of the parish came within the city liberties, and from the date of this change the parish gained the name of St. John the Baptist in Bedwardine. The chapel, which became the parish church, is close on the boundary of the city liberties, and if Bedwardine can be correctly read as boundary, St. John's, as soon as its chapelry was done away with and it had no defined limits in the city, was at once called St. John in Bedwardine.

If Worcester was walled in in 894 so as to ensure the town against raids by land and by river, one very interesting point arises. The walls do not seem to have ever extended along the whole of the west or river side. A space of 300 or 400 yards on the Quay was always left without a wall. On the south side the wall terminated at the corner of the garden of the Bishop's Palace; on the north it did not come below the corner of Quay Street; thus leaving a long open space, where if any one landed they could rush the town. There must be some reason why this was so. It will be noticed in all the plans of Worcester that there were no forts or defensive works on the west bank of the river, and in none of the accounts of the attacks on Worcester is mention made of any. The obvious reason seems to be that the water on that side was too deep to permit even at low tide the river to be forded, and so no wall or bank were needed. That the west was the deep-water side appears to be the case; even now the bed of the river naturally shelves that way. Until, therefore, a better reason is put forward, it may be said that no defensive works were required there, as except at the ford under the fort the river was not passable. There still, however, remains the case of raiders from the river. The quay, which would be open for the landing of goods, would also be open for the landing of pirates unless there was something to prevent them reaching it. A possible and not improbable explanation may be that the river was well protected if the bridge was below the Quay. 
There must have been a bridge over the river at Worcester at an early date-when it is difficult to say. The earliest mention is not until 1265, when, after Prince Edward escaped from Ludlow, the bridges over the Severn, including Worcester, were broken down in order to prevent Simon de Montfort joining his son, and it was only by the local knowledge of Bishop Cantilupe of a ford lower down the river near his palace at Kempsey, that Simon was able to cross to his death at Evesham. Whether the first bridge was stone or wood does not appear. It was repaired and largely used during Edward I.'s reign, but does not seem to have been very conrenient, for when the new stone bridge was built, about 1314, the Prior and convent alleged that the conflux of strangers coming to pass over the Severn, there being no bridge between Gloucester and Bridgenorth but at Worcester, was so great that they could not, on account of the cost, keep up their full number of fifty monks; so to relieve their necessities the Bishop appropriated to them the church of Dodderhill, otherwise the Hill Church in Wich. ${ }^{1}$

In 1313 the Worcester monks sent round to collect subscriptions for rebuilding the bridge. The Prior wrote to all archdeacons and their officials-deans, rectors, vicars and chaplains and other ministers in churches and chapels throughout the city and diocese of Worcesterthat when $R$. de B., the proctor or envoy of the great bridge over the Severn at Worcester, or T. de W., his substitute, should come there to beg the alms of the faithful that they be admitted kindly and without contradiction, and whatever be collected be handed to them, and if any impede the same proctor in collecting the alms of the faithful that they be restrained by ecclesiastical censure and cited to appear before the Prior or his commissaries. ${ }^{2}$ The bridge then built is said to have lasted for over four and a-half centuries; it was pulled down in September 1781 .

There seems to be no record of a bridge at Worcester having ever been at any other site than that where the fourteenth-century bridge stood. But it is by no means 
clear that this was the site of the earlier bridge, which was broken down in 1265, and inference would lead to the conclusion that it was not. If the bridge was on or near the site of the ford it would be guarded by the fort, but it would do more: it would be a strong protection against any marauders coming up the river, as at high water they could hardly pass under such a bridge as would then have been built; at low tide it is doubtful if there would be sufficient water to take the piratical boats over the Diglis shoal. Thus the bridge, if near the cathedral, would form an effective barrier to navigation up to the Quay and would furnish a reason why the walls were not carried along the whole length of the river bank. It should be added that there is not any evidence to show that a bridge ever did exist at this spot. All the evidence points only to the site of the 1313 bridge. This, however, does not explain how the Quay was defended from any enemy coming down the river; as to this, except the fact that it does not seem likely that any enemy would descend the river in boats in those days, as there would be great difficulty in their return up the stream and over the fords that then existed in the river, there is nothing to be said. The fact of the open space at the Quays, still remains one of the puzzles connected with old Worcester that has to be cleared up. There is also the point why it was that no defensive works existed on the west side of the river; this seems to have been the case all through the history of the place. As to this again, the only explanation is a conjectural one, that the deep water adjoining the west bank rendered works needless, as it was impossible to ford the river here. This again is not satisfactory, but no other explanation can with our present knowledge, or rather want of knowledge, be offered.

If it is accepted that the area that was included inside the Saxon walls was the same that was included in the walls as they subsequently stood, then the development of Worcester becomes fairly certain. The line of the Worcester walls as they existed up to the time of their destruction was certainly the same from the beginning of the thirteenth century, and it is clear that within the walls a great deal of land that was.then unbuilt on was 
included. There is not anything to show that there was any enlargement of area between the building of Ethelfred's wall about 894 to the time of John. When after the city had received a garrison on behalf of the Dauphin, William, Marshal Earl of Chester retook it for the King, a question arose as to demolishing the walls of the rebellious city that had welcomed the French. John, however, agreed, in consideration of the payment of $£ 100$ by the citizens, not to pull down the walls. This agreement is stated in a writ on the Patent Roll. ${ }^{1}$

"The King to John Marshall and his bailiffs greeting. We order you that you pay to our well-beloved and faithful William Earl Marshal, guardian of ourself and our kingdom, the $£ 100$ which the men of Worcester promised to pay to the late John of blessed memory, our father, formerly King of England, in order that the walls of Worcester be not thrown down and that the town of Worcester remain safe from fire and destruction. And if the said men of Worcester do not pay the said $£ 100$ the walls of Worcester be levelled without delay, as our father, which yet living, ordered you. In witness whereof these our letters patent, sealed with the seal of William Earl Marshal, we have sent you. Witness the said Earl at Gloucester the 1st December in the first year of our reign (1216)."

This writ clearly proves the fact of the walls of Worcester being then standing. It seems probable that the money was paid so the walls remained standing, but the town was greatly put to it to raise the money. The Monks had to assist, and to do so the metal work round the shrine of the Sainted Wulstan had to be melted down to enable the monks to raise 300 marks.

That the walls then followed the same line as now is shown by another writ of Henry III. The walls then and subsequently ran from St. Martin's Gate to Sidbury in a line, roughly, from north to south. Remains of this part of the wall still exist. Between 1225 and 1230 - the exact date is not known-the Franciscans or Minorite Friars settled in Worcester. The site of their house is shown by the name "Friar Street," and it ran from the street to the wall, the exact spot being the old city prison, now the Laslett Almshouses. The house was inside the wall, the church and cemetery outside, and the only way of communication between the two

11 Henry III. m. 15. Mr. St. John Hope has given me this reference. 
was a small postern in the wall which was not wide enough to permit the brethren to bring in or take out the necessaries for the house. The Friars had sufficient influence to obtain in 1231 an order from the King directing the Bailiffs of Worcester to so enlarge the postern as to make it more convenient for their use. The writ which did this is on the Close Rolls, ${ }^{1}$ and is as follows:-

"The King to the friars minors.

"The King on the petition of the friars minors of Worcester has granted that the postern which is in the wall of Worcester at the house of the brethren be made larger, so that their wood and other necessaries may be carried through the same postern, or that a competent road may be made for them elsewhere to carry in their goods. It is therefore ordered the bailiffs of Worcester that they make the said postern larger or make elsewhere a fit road to carry in their necessaries. Witness, Worcester, September 26."

It does not appear what the Bailiffs did to carry out the writ. 'The Postern, or Friars' Gate, as it was afterwards called, remained a postern, and is spoken of 300 years afterwards by Leland when he visited Worcester about 1536. The Friars found that the alterations the Bailiffs made under the writ did not satisfy all their requirements. They were a prosperous House, and soon outgrew the space they had inside the wall. Between 1236 and 1239 they acquired a new site outside the walls in addition to the old one inside. This required a further postern and on application to the King they obtained this in $1246,{ }^{2}$ with the safeguard, however, " if the enlargement was" not to the damage of the city." That it did damage the city by weakening the defences seems to have been the case, as somewhere here an additional fort or blockhouse was erected outside the wall to cover the gate, a fort that has given its modern name to this part of the city.

These writs of Henry III. therefore prove two points, the existence of the city walls in the thirteenth century, and the fact that they then ran upon the lines that they subsequently tollowed, and as far as is known always followed. That line was, beginning at the Bridge near St. Clement's Church, it ran up the street known as the Butts, across Angel Street, through the

115 Hen. III. m. 2.

2 Close 30 Hen. III. m. 2. 
grounds of the Berkeley Hospital, across Foregate Street, down Sasome Street, along Watercourse Alley, over Silver Street, then in a line parallel to Friar Street and New Street, across Sidbury, enclosing St. Peter's Church, and terminating in the wall of the old enclosure of the settlement at its eastern corner. The enclosure of the settlement then extended to the river, and a wall, the wall of the Monastery, ran alongside the river up to the south end of the Quay, where it terminated. Another wall at the north end of the Quay ran along the river until it reached the bridge where the wall started.

That the wall enclosed a large space of unbuilt land is shown from a reference to another body of Friars, the Friars of the Sack or " of the penance of Jesus Christ." They also had a house on or just inside the City Wall between it and a street which still exists, called "Dolday." In 1272, the Friars applied to the King to grant them the street called "Dolday," 120 feet in length. $\AA$ writ ad quod damnum was issued and an inquest held to inquire

"whether it was to the damage of the King or the harm of the vill of Worcester if the King granted to the Friars de pœnitentia Jeshu Christi of Worcester, a certain street called Dolday, to enlarge their place in the same vill and the said street contains in length seven score feet and in breadth 11 feet."

The jury found that

"it was not to the damage of the King nor harm of the vill of Worcester, but rather to the profit and honour of the King and the profit of the citizens if the grant was made."

From the Patent Roll it appears that the grant was made, but two years later, at the Council of Lyons (1274), this order of Friars was suppressed. In some way the devolution is not quite clear; the site of the Priory became the property of the Beauchamps, and in 1347, William Beauchamp, the Lord of Elmley, obtained a licence in mortmain to grant the land to the Friars Preachers," they held the place up to the time of the dissolution, giving it the name, by which it is still known, "Black Friars," a street running parallel with Dolday at right angles to the City Walls. XIX.

1 Inq. P.M. (W. H. S.), p. 12, No.

2 Patent 21 Ed. III., pt. IV, m. 14. 
The site of this house was 100 perches long by 30 perches broad. Four years after it was founded, in 1351, William Beauchamp obtained a licence in mortmain to grant the Dominicans a further two acres of land adjoining their house. ${ }^{1}$ In 1391, Richard II. granted them a garden for the enlargement of theirs. ${ }^{2}$ This garden was between the City Walls on the one side, and the way called Dolday on the other. From these grants it is obvious that along and adjoining the north wall of the city there was a considerable area of land which was not built upon. As there is nothing to show that on this side the city the north wall ever ran along any course other than what it then did, it is not an unfair inference that the north wall was on the line of the existing wall. If this is so and the line of the east wall was also the same as shown by the Grey Friars' house, it seems to follow that the Worcester walls from the first included the same area they subsequently did, and if it is asked what the area was, the answer must be the parish of St. Helen and such portions of other parishes as it was convenient to include.

Having traced the history of the walls of the town in order to complete the story of the development of Worcester, it is necessary to go back to the tump, and tell how Worcester came to have a castle. For the latter part of Anglo-Saxon times no one in Worcestershire takes a more prominent place than St. Oswald. He became Bishop of Worcester in 961 , a young man just returned from the great Benedictine House of Fleury and most zealous to extend the Benedictine rule in England. The Worcester clergy had become very slack in the observance of any regular rule of life. Oswald was most anxious to reform them and establish the rule of St Benedict. The first question that arises in connection with his episcopate is what did he find when he arrived at Worcester? In the Rolls edition of the Historians of the Church of York, for the life of Archbishop Oswald no less than three lives of Oswald are given. The two most important are those by Eadmer and the Prior of Worcester Senatus. Each of these writers says that on Oswald becoming Bishop of Worcester he began to build a monastery. But it is said he went much further, as the existing

1 Patent 24 Ed. III., pt. I, m. 29.

- Patent 15 Ric. II,. pt. I, m. 30. 
Worcester House would not adopt his views as to the Benedictine rule. He began to build a new church on the tump, the Cathedral of St. Mary. Others say that the Cathedral of St. Mary was already in existence. Whichever is the true account, one thing is quite clear, that Oswald either built or restored and enlarged an already existing church $n$ the tump, and set up in it a rival service to that of the Worcester monks. It was more attractive. Some persons say that Oswald had brought with him from Fleury the ancient mode of chanting the service, not filtered through Norman abbies, as was afterwards the case, and that the remains of it are still to be traced in some special hymns and chants to be found only in the Worcester service books. Whatever it was, Oswald's church filled while the Monks' church was deserted, with the result that the offerings at Oswald's church increased while those in the Monastic church derreased. After a contest extending over some years, in 969 the Worcester monks surrendered to Oswald, and he became supreme. From this time there is no doubt that there were two churches on the tump, St Michael's the parish church, and the Cathedral of St. Mary's. But it is usually said there were three: St. Michael's the parish church (this is common ground); St. Mary's, Oswald's church, which he either built, or rebuilt, and St. Peter's. As has already been stated, there is a Parish Church of St. Peter, just outside the enclosure of the monastery and it seems very unlikely that there should have been a St. Peter's outside and a St. Peter's inside the wall. The fact that St. Mary and St. Peter had a cemetery in common through which the wall of the monastery went, rather points to the one church inside and the other outside the monastic enclosure. It is also remarkable that if the two churches, St. Mary's and St. Peter's, were both inside the enclosure there should be no tradition or record as to the sites of these two churches. It is true that they might have been in reality one church and that Eadmer's words-

"Monasterium infra ipsam sedem episcopalem construere coepit . . . . Perfectam ecclesiam ipse in honore sancto et perpetuce virginis dei genitricis marice dedicavit ibique ut proposuerat monachos in sancta conversatione Christo servituros congregavit" 
merely mean he built some such building for common living as he had seen at Fleury with a chapel to it for the use of his monks, not a large church for the general use of the town. Senatus rather inclines to this view; he says :

"Monasterium infra ipsius urbis scepta construere copit in habitationem monachorum."

That Oswald's great object was to establish a Benedictine Monastery is clear from a passage in the anonymous life which, after describing the surrender of Wynsin, says :

"et illis qui sub eo erant in civitate anteposuit Wynsinum reverendum presbyterum qui erat apud nostri crenobii gymnasium eruditus cui annexuit quosdam fratres ex nostro choro."

This seems to indicate that to some extent St. Helen's was one of the, if not the church of the Worcester seculars. Against the view here put forward that there were only in the enclosure of the monastery two churches, St. Michael's and St. Mary's, and that St. Peter's was the St. Peter outside, two facts should be stated. Oswald in his contest with the Worcester monks had a troublesome opponent named Wulfgar; when the monk surrendered and Wynsin was made Prior, Oswald gave Wulfgar the church of St. Peter by the south wall.- This distinguishing description of St. Peter's church, which obviously refers to the parochial church of St. Peter, at first sight leads to the inference that the church of St. Peter outside the wall differed from the church of St. Peter inside; hence the additional name. It is, however, not a little remarkable that this seems to be the first time any addition is made to the name of the church of St. Peter, and it may well be that to emphasize his victory and to make it quite clear that St. Peter's had nothing further to do with the monastery or the see of $W$ orcester, the addition was made to the name, not to distinguish it from another St. Peter's but to put an end once and for all to any claims that church could make to be other than a parish church by showing by her very name that the site was a mere accident and gave her no rights or privileges, and that, as William of Malmesbury expresses it, the janitrix cali triumphed over the claviger paradisi.

p. 77 . 


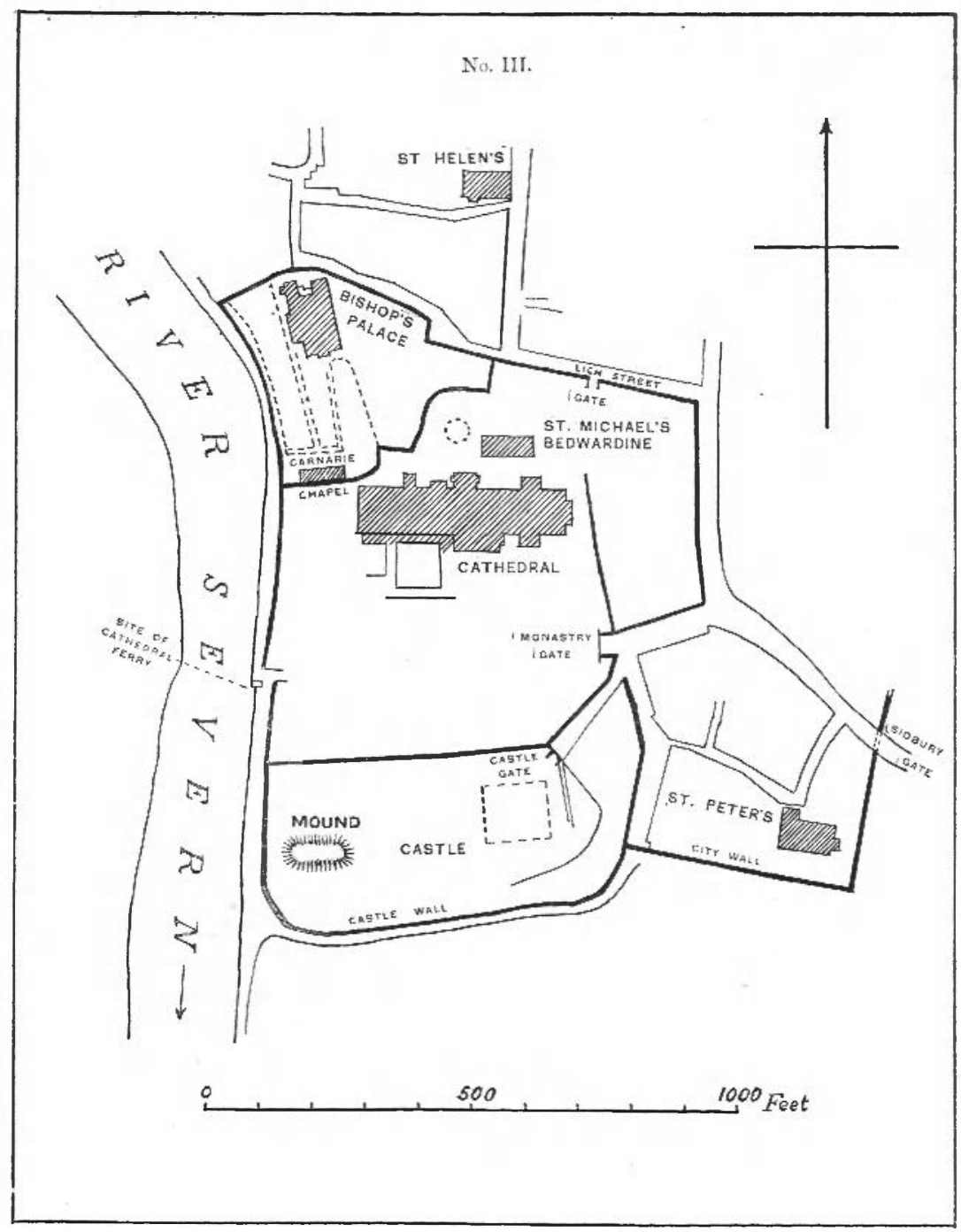


The other point is that in later times there were certainly two churches of St. Peter, and St. Peter by the south wall became known as St. Peter the Great to distinguish it from the other St. Peter. There is not very much known of the other St. Peter, and it is most likely that it did not come into existence until some time after Oswald's death. The first mention I have been able to find of it is in 1276 , when William Beauchamp, Earl of Warwick, who was then hereditary keeper of the Castle of Worcester, presented Richard de Powick to the Chapel of St. Peter in the Castle of Worcester. ${ }^{1}$ From this it seems fairly clear that the Chapel of St. Peter of the Castle was merely a chapel for the use of the Castle, and until the Castle was built was not in existence. At all events, it could not have been the monastic church of St. Peter, for being part of the Castle, it was outside the monastic enclosure, and had any of the keepers of Worcester Castle attempted to make any monastic church part of their castle, we have sufficient details of the long quarrel between the monks, the keeper of the Castle and the Sheriff to be quite sure some mention of it would have been made. As nothing of the sort appears, it is only fair to conclude that the Chapel of St. Peter in the Castle of Worcester had nothing to do either with the early parish church of St. Peter or with the monastic church of the same saint, if there was one, but was part of the Castle.

This brings up the question, When was the Castle of Worcester built? The eighteenth century historians of Worcester give it a very early origin. Green says-_2

"That there was a fortress of the Romans here, afterwards turned into a citadel by the Saxons and honoured by the residence of the Viceroys of the Wiccii, is sufficiently credible, though history affords no direct and positive proof of it."

The earliest mention of a castle that I am aware of is in a charter of Oswald's in $989,{ }^{3}$ which says :

"Ego Oswaldus divina favente clementia archiepiscopus quandam particulam telluris de Monasterio Sanctce Marice in Wiogonna castello videlicet unam mansam et dimidam in loco nuncupante Northtun, etc."

1 Giff. Reg. (W. H. S.), 89.

2 I, p. 246. 671.

${ }^{3}$ Kemble Cod. Dipl. III, 247, No. 
Assuming the charter to be genuine-and Kemble does not star it -it seems at first sight to say that the Monastery of St. Mary was in the Castle of Worcester, yet this cannot be its meaning. Castellum cannot possibly here mean castle in its modern sense of the word. It must mean the fortress or town of Worcester. There is some evidence that no castle in the modern sense existed in 1041. When Hardicanute's husscarls were sent to collect the Danegelt in that year, the Worcester citizens refused to pay, a riot ensued; the husscarls fled for shelter to a tower of the monastery.' Had there been a castle then in existence in which they could have taken refuge it is more probable that they, the royal servants, would have fled to the royal Castle, where they would have been safe, rather than to the monastery where they might not. It will be observed it was to a tower of the monastery, not to the church or sanctuary that they fled.

There is also evidence that some three years after the Conquest, in 1069, Urso d'Abitot, the Norman Sheriff, began to carry out some works at Worcester. These works were said to be making a castle, and were on the tump on the south side of the monastery between it and the Frog Brook. In carrying out his works the monks said that he took in a portion of their cemetery. What precisely was it that Urso built? All the writers of Mr. Freeman's school say a castle, a castle of stone : ${ }^{2}$

"the badge of the great change to which the Norman Conquest had put the finishing stroke."

Excavation-and the excavation has been thorough, for the castle has been carted away - has disclosed no remains of a stone castle. What it has shown is that there was an entrenched area on which stood an artificial mound composed of sand and gravel on sandstone foundations ; the west base of the mound close to the river; the apex of the mound was 80 feet above the high water mark ot the river. ${ }^{3}$ This mound, or "motte," was what Urso constructed for defensive purposes, a cone-shaped barrow

\footnotetext{
1 Anglo-Saxon Chron., V, Rolls ed. II, 2 Norman Conquest, 648. 732, Flor. Wig. Eng. Hist. Soc., I, 195. $\quad{ }^{3}$ Allies, -Antiquities, etc., p. 15.
} 
surrounded by a ditch, with a stockade on the summit. ${ }^{1}$ The barrow stood in an enclosed drea, a base court or building, surrounded by a bank and a ditch. It was this enclosure that encroached on the land of the Monastery, enclosed part of its property, and led to the dispute between the Sheriff of Worcestershire and the Monks that lasted until 1217, when, under Henry III., the enclosed piece was restored to them. All the old plans of Worcester, from that of Speed in the sixteenth century to that of Chambers in the nineteenth, show this motte of Urso's standing on the south side of the Monastery near the river. It seems a simple mode of defence, but the mound, ditch and palisade proved very effective. In 1088 the Anglo-Saxor. Chronicle, speaking of the rebellion on the Welsh Marches, says:

"and the chief men of Hereford and all that shire forthwith and the men of Shropshire with many people from Brytland (Wales) came and harried and burnt in Worcestershire on till they came to the city itself, and would then burn the city, plunder the monastery and win the king's castle into their hands." "?

Here the motte is called the King's Castle. The rebels did not attack it, so there was no opportunity to show the strength of Urso's work.

Although the motte was standing in 1086, when the Domesday survey was made, there is no mention therein of a castle at Worcester, possibly because it furnished nothing to tax. Only one castle in the county, that of William Fitz Ansculf at Dudley, is mentioned, and this was possibly a stone castle on the motte. In 1140 the Empress Maud took Worcester, but failed to carry the motte or castle. It is said the Castle was erected at this time, but it probably means that additional works were thrown up to guard the bailey. ${ }^{3}$

Ten years later, in 1149, Stephen took and burnt Worcester, but was unable to take the Castle. Although regularly besieged he failed to carry it. ${ }^{4}$

In 1216 William Marshall, son of the Earl of Pembroke, held the Castle for the Dauphin. ${ }^{5}$ In July

${ }^{1}$ See Mrs. Armitage's paper, English Historical Review, XIX, pp. 209 and 454; Archaologia, LVIII, p. 313. Round Geoffrey de Mandeville, Appendix 0, p. 328.
2 Anglo-Saxon Chronicle, Rolls ed. II, p. 192.

119.

Flor. Wig. (Eng. Hist. Soc.), II,

+ Hen. Hunt Rolls series, 282.

Inn. Monast., IV, 406. 
of that year the Earl of Chester surprised and carried it for the King. This led to the Agreement of 1217, which settled the quarrel between the Monastery and the Castle as to the enclosure of Urso. The Worcester annalist thus records it :-

"The Castle of Worcester is surrendered to us as part of our property as far as the motte tower on the eve of Easter by the King's writ under the seal of William Marshall his guardian, and Bishop Sylvester excommunicated all who did anything against it.",

The "motte tower" the King retained in his own hands, but granted the custody of it to Walter de Beauchamp. Probably the buildings that were built were erected between this grant and the year 1263, as in that year a force of the rebel Barons under Robert de Ferrers, Earl of Derbyshire and Staffordshire, attacked and took Worcester, making their entrance by the old castle. ${ }^{2}$

"Cui cum cives muralia civitatis et portas custodiendo viriliter restitissent tandem ex inopinato per vetus castrum intravit qui et villam destruxit ac Judaismum evertit."

This period of building would also be the time of the erection of the Chapel of St. Peter in the Castle, and it may well be that the presentation of Richard de Powick in 1276 was the first presentation to $i^{3}$ made by William de Beauchamp, who was the keeper of the Castle for the King as sheriff. There does not appear to be any precise record as to what the buildings of the Castle were.

From this time onwards the history of the Castle does not directly affect the story of the development of Worcester. As the sheriff was the King's officer he kept the King's prisoners in the Castle, and this led to the Castle degenerating into the county prison; so it remained until 1833, when the judges of assize, under threat of indictment, compelled the county to build a new prison. The Crown then sold the site of the Castle, the mound was carted away, and the land on which the motte stood is now the play-ground of the boys in the Cathedral school. Traces of the wall separating the bailey of the Castle from the Monastery can still be seen, but the rampart which formed the southern defence against the Frog Brook has completely disappeared.

1 Ann. Monast., IV, 407.

2 Matt. West, Flores Historiarum, 3 Giffard Reg. (W. H. S.), p. 89. Rolls Series, II, 486. 


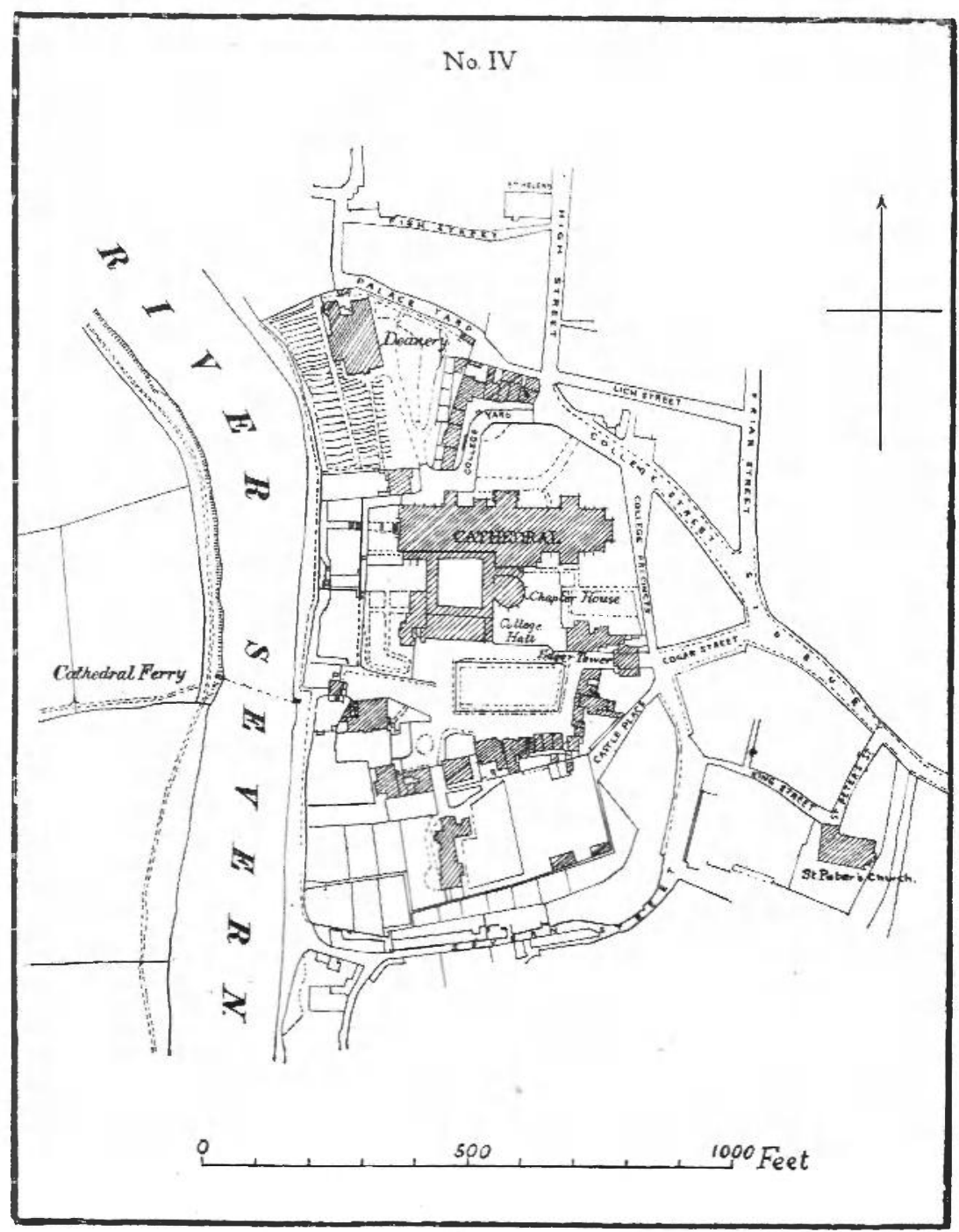


The tump had a final development. Up to the time of the Conquest, so far as is known, the bishop lived with the monks in the Monastery. Wulstan appears to have been the first bishop to have given up the custom and dwelt by himself. When he did this does not appear, but it was before 1088, for on the attack of the Marcher Lords on Worcester in that year, it is said by Florence of Worcester that the bishop retired with the others into the Castle. ${ }^{\prime}$ The precise position of the new residence appears in an account of the building of the chapel to the Carnarie in 1224, which is said to have been built in that year between the Cathedral and the bishop's palace. ${ }^{2}$ In 1270 Bishop Giffard obtained the King's licence to crenellate the palace and fortify it with an enclosure of embattled walls. This he carried out. Beginning at the north-west corner of the Priory wall, he carried on the wall enclosing his palace a little distance along the river, and then turning sharp to the east, continued the wall round the corner of the tump until it joined the old Monastery wall at an acute angle.

This enclosure was the last that was made on the tump and completed its occupation. The old palace is the present Deanery and some remains of Giffard's work are still to be seen in it. Part of it formed the bishop's prison, and the bishop's registers have frequent entries of clerks being appointed by the bishop to demand from the King's judges the delivery up to the bishop of any clerks charged with a criminal offence ; these clerks on delivery were taken from the Castle and placed in the bishop's prison. That is, the prisoners were conveyed from the south-east corner of the tump, the King's prison, and formally handed over to the bishop's nominee, who took the prisoners to the north-west corner of the tump, the bishop's prison. Possibly the prisoners were quite as happy or happier in the King's prison as in the bishop's.

Such is a rough outline of the evolution of Worcester. It is really the story of the tump. It starts with early, possibly prehistoric, times, when at the intersection of two forest tracks near a tidal ford some persons dwelt to guide or guard travellers crossing the ford. Then came

1 Flor. Wig. (Eng. Hist. Soc.), II, 26. ニ Habington. 
the necessity of making a safe place for the shelter of the guardians of the ford, and this was done by throwing up a bank round the few huts. Missionaries came, and after ingratiating themselves with the inhabitants, were allowed to dwell in the shelter; this led to the Monastery becoming part of the settlement. The Monastery increased and enclosed a space of its own. Then came other inhabitants who dwelt round the settlement, and after a time, for their own protection, enclosed the town by walls. Then came the Norman fortifications, a motte and a bailey or courtyard. Then a stone castle, which degenerated into the ordinary prison, while the last remaining. corner of the tump was enclosed by the bishop, whio, under royal licence, built a defensive house surrounded by its own walls, the last feature in the general development of the tump.

Ford, Settlement, Monastery, Castle, Mound, Palace, seem to be the successive steps in development which turned Worcester from a few huts into a flourishing city. 